Int. J. Dev. Biol. 48: 857-865 (2004)

doi: $10.1387 / \mathrm{ijdb} .041871 \mathrm{pz}$

\title{
Regulation of cell adhesion and migration in lens development
}

\author{
PEGGY S. ZELENKA* \\ National Eye Institute, NIH, Bethesda, MD, USA
}

\begin{abstract}
Cell movements during lens development and differentiation involve dynamic regulation of cell-matrix and cell-cell adhesion. How these processes are regulated depends on the particular array of matrix components and adhesion proteins that are expressed, as well as the signaling pathways that affect them. This review examines what is known about adhesion proteins and their regulation in the lens in light of recent findings about the mechanism of cell migration. The characteristic shape and organization of the lens depends on highly regulated cell movements during development and differentiation. Epithelial cells at the equator migrate posteriorly, bringing them into contact with factors in the vitreous humor and initiating differentiation. Elongation of the differentiating fiber cells is coupled with directed migration, posteriorly along the capsule and anteriorly along the fiber cell-epithelial interface, to generate a symmetrically organized fiber cell mass with aligned suture planes. To make these movements, cells systematically create and dissolve cell-cell and cell-matrix adhesions, form connections between these adhesions and the cytoskeleton, and generate contractile force. Since errors in cell migration may lead to aberrant lens shape or misplacement of the lens sutures, precise regulation of each step is essential for the optical quality of the lens. Recent advances in cellular developmental biology have begun to shed light on the molecular mechanisms underlying cell movements and the changes in adhesion that make them possible. This review will summarize those findings and relate them to relevant studies of the lens to provide an outline of the cellular events that lead to lens morphogenesis.
\end{abstract}

KEY WORDS: extracellular matrix, integrin, Rho GTPase, actin cytoskeleton, Cdk5

\section{Introduction}

The characteristic shape and organization of the lens depends on highly regulated cell movements during development and differentiation (Piatigorsky, 1981). Epithelial cells at the equator migrate posteriorly, bringing them into contact with factors in the vitreous humor and initiating differentiation. Elongation of the differentiating fiber cells is coupled with directed migration, posteriorly along the capsule and anteriorly along the fiber cell-epithelial interface, to generate a symmetrically organized fiber cell mass with aligned suture planes (Fig. 1). To make these movements, cells systematically create and dissolve cell-cell and cell-matrix adhesions, form connections between these adhesions and the cytoskeleton, and generate contractile force. Since errors in cell migration may lead to aberrant lens shape or misplacement of the lens sutures, precise regulation of each step is essential for the optical quality of the lens (Kuszak et al., 1994). Recent advances in cellular developmental biology have begun to shed light on the molecular mechanisms underlying cell movements and the changes in adhesion that make them possible. This review will summarize those findings and relate them to relevant studies of the lens to provide an outline of the cellular events that lead to lens morphogenesis. Because of journal space restrictions, many relevant references could not be cited. Where possible, citations refer to key articles or to review articles with more comprehensive bibliographies.

\section{A brief summary of cell migration}

Studies of migrating fibroblasts have shown that migration involves several distinguishable steps, which include extension, attachment to the substratum, forward displacement of the nucleus and cytoplasmic contents, detachment from the substratum at the

\footnotetext{
Abbreviations used in this paper: ECM, extracellular matrix; SPARC, secreted protein acidic and rich in cysteine;IP3, inositol $(3,4,5)$ trisphosphate; $\mathrm{PI}(4,5) \mathrm{P} 2$, phosphatidylinositol $(4,5)$ bisphosphate; $\mathrm{PKC}$, protein kinase C; BAPTA-AM, 1,2-bis (2-aminophenoxy) ethane-N,N,N',N'-tetraacetic acid tetrakis(acetoxymethyl ester); MLCK, myosin light chain kinase; ERM, ezrin-radixin-moesin; FAK, focal adhesion kinase; BMC, basement membrane complex; IgCAM, immunoglobulin superfamily cell adhesion molecules
}

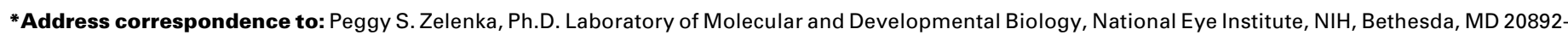
0704, USA. Fax: +1-301-435-7682. e-mail: zelenkap@nei.nih.gov 


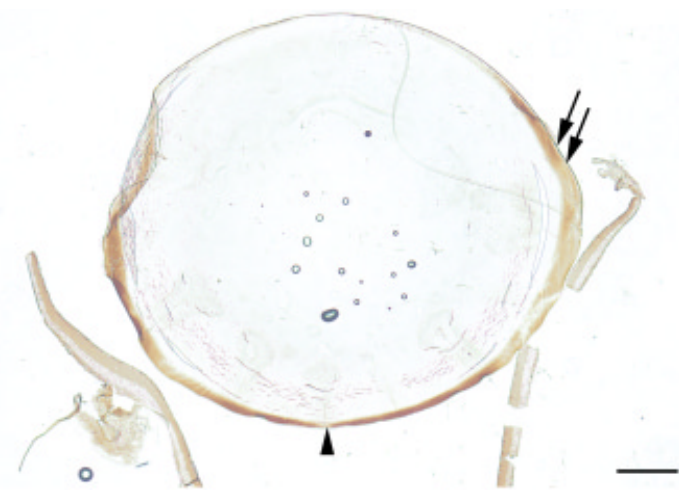

Fig. 1. Cell movements during lens differentiation. Immunostaining for Cdk5, a kinase that regulates cell adhesion and migration (Negash et al., 2002; Gao et al., 2004) illustrates regions of active cell migration in the mouse lens. At the lens equator (double arrow), epithelial cells migrate posteriorly and begin to elongate to form fiber cells. Elongating fiber cells then extend both anteriorly, along the epithelial-fiber interface, and posteriorly, along the capsule. Like many proteins involved in cell adhesion and migration, Cdk5 is most concentrated in the tips of elongating fiber cells. Scale bar, $250 \mu \mathrm{m}$.

trailing edge, followed by retraction of the tail ( Holly et al., 2000; Etienne-Manneville and Hall, 2002). The extension of a lamellipodium or filopodium at the leading edge is driven by polymerization of actin filaments and is regulated by actin capping proteins (Allen, 2003;Fischer et al., 2003) and small G-proteins of the Rho-family (Etienne-Manneville and Hall, 2002). Once an extension has been formed, integrins on the ventral surface bind to extracellular matrix components to form weak attachments. These contacts are rapidly strengthened by the clustering of integrins in the membrane and the attachment of a variety of signaling and scaffolding proteins to the cytoplasmic domain of the integrins and integrin associated proteins, forming a focal contact. Proteins that bind directly to filamentous actin, such as talin, tensin, and $\alpha$-actinin, are recruited to these contacts, providing a link between the extracellular matrix and the actin cytoskeleton. Displacement of the nucleus and cytoplasmic contents then occurs by myosin-dependent contraction of the actin cytoskeleton against these attachments. Finally, local disassembly of focal adhesions at the trailing edge of the cell releases the cell from the substratum and the trailing uropod is retracted into the cell body. While selective polymerization, depolymerization, and contraction of the actin cytoskeleton underlie all these cell movements, a high degree of spatial and temporal organization is also required to yield directed cell movement. Microtubules have been shown to play a role in this organization, possibly by directing the flow of membrane components and regulatory enzymes into the leading or trailing edges. It is also important to note that the relationship between adhesion and migration is biphasic (Holly et al., 2000). That is, the highest rate of migration occurs at intermediate adhesive strength. Very high adhesive strength hampers migration by inhibiting detachment, but very low adhesive strength may also result in slower migration by failing to provide the necessary traction. Clearly, coordination of the various events involved in migration is essential for efficient, directed migration.

Although epithelial cell migration differs in several important respects from the picture derived from studies of fibroblasts, the molecular mechanisms may yet be similar. One important characteristic of epithelial cells not seen in fibroblasts is the ability to migrate as an intact sheet, rather than as individual cells. This is a biologically significant feature, which preserves the barrier function of the epithelium. Nevertheless, migrating epithelial cell sheets exhibit some characteristics of migrating fibroblasts. As in migrating fibroblasts, cells along the leading edge form lamellipodia and generate force. Moreover, as in fibroblasts, these processes are driven by actin polymerization under control of the Rho-family GTPase, Rac (Fenteany et al., 2000). Interestingly, cells distal to the leading edge also generate force and have sites that promote Rac-dependent actin filament assembly, although they do not appear to form lamellipodia (Fenteany, $2000 \# 1393$ \}. Actin fibrils perpendicular to the leading edge of the migrating epithelial cell sheet seem to connect a number of cells, and may generate the contractile force necessary to pull the epithelial sheet in the direction of movement (Fenteany et al., 2000). This may be analogous to the myosin-dependent contraction in fibroblasts which serves to move the cytoplasmic contents and retract the uropod. In addition, some epithelia also have a uniquely epithelial structure referred to as a "purse-string". The purse-string is a continuous actin bundle parallel to the migrating cell front, which surrounds the wound when the epithelium is wounded. In some cases, contraction of this actin bundle may contribute to cell migration by exerting contractile force on the cells. Finally, although epithelial cells do not form focal adhesions of the type observed in fibroblasts, many of the proteins that contribute to focal adhesion complexes in fibroblasts are also involved in epithelial cellsubstrate attachment.

\section{Lens extracellular matrix}

The ability of a cell to recognize and interact with specific ECM components is a fundamental requirement of cell migration. Alterations in ECM composition that interfere with these interactions can lead to defects in migration that alter tissue morphogenesis and the state of differentiation (Juliano and Haskill, 1993). In the lens, the ECM is represented by the lens capsule, which is primarily composed of collagen IV, laminin, and fibronectin (Cammarata et al., 1986). As might be expected, lens epithelial cells in culture attach and spread well on these substrates, providing direct evidence that they recognize and bind these components ( Oharazawa et al., 1999; Negash et al., 2002) (Fig. 2). However, these are by no means the only components of the capsule. The capsule also contains a number of glycoproteins and proteoglycans, including SPARC (Yan et al., 2000), tenascin (Menko et al., 1998), entactin (Cammarata et al., 1986), perlecan (Dong etal., 2002b), thrombospondin-1 (Hiscott etal., 1996;Tucker et al., 1997) and bamacan (Hawse et al., 2003). Although these proteins are not major structural components of the capsule, they may have important functions and in some instances their absence leads to gross structural abnormalities of the lens.

Homozygous deletion of the gene for the glycoprotein, SPARC (also called osteonectin or BM-40), demonstrates the critical importance of certain extracellular matrix glycoproteins for lens development. SPARC is a calcium binding protein involved in organization of collagen IV. It also binds to a range of other capsule components, such as thrombospondin-I, tenascin, and osteopontin (Lane and Sage, 1994). Homozygous deletion of 
SPARC causes structural abnormalities in the lens capsule posterior to the bow region, accompanied by severe age-onset cataracts and disruption of the lens (Gilmour et al., 1998; Bassuk et al., 1999). One of the earliest abnormalities observed in the lenses of these animals is an apparent inability of the fiber cells to elongate posteriorly (Bassuk et al., 1999). Since in vitro studies have associated SPARC with disassembly of focal adhesions and loss of cell-matrix adhesion (Lane and Sage, 1994; MurphyUllrich et al., 1995) it is possible that this elongation defect may result from an inability of fiber cells to carry out the dissociation step required for migration. Interestingly, SPARC also inhibits the proliferation of some cell types, by a mechanism that is independent of its anti-adhesive properties (Murphy-Ullrich et al., 1995). Since cell proliferation in lenses of SPARC -/- mice does not seem to be abnormal, SPARC may not exert an anti-proliferative effect on lens epithelial cells. However, this question has not been examined directly.

Another glycoprotein component of the lens capsule that seems to be important for proper fiber cell elongation is entactin1 (nidogen). Entactin has been shown to bind to laminin and collagen IV, and is thought to form a stabilizing bridge between them (Timpl and Brown, 1996). Like SPARC, entactin also binds other matrix components, such as fibronectin (Hsieh et al., 1994)and perlecan (Kvansakul et al., 2001). Mice deficient for entactin have structural defects in the posterior lens capsule. Rather than migrating evenly along the inner surface of the capsule, elongating fibers form protrusions into the matrix and fail to form the posterior suture (Dong et al., 2002a). Cells attach to entactin- 1 via $\alpha 3 \beta 1$ and $\alpha v \beta 3$ integrins on their surfaces (Dong et al., 1995).

One additional capsule component that has attracted attention recently is bamacan. Bamacan is a secreted condroitin sulfate proteoglycan found in most basement membranes. Interestingly, the core protein also has intracellular roles in DNA repair and in stabilizing sister chromatid separation during mitosis. Increases in beta-catenin transcriptional activity can lead to overexpression of bamecan, a common feature of certain human cancers (Ghiselli and lozzo, 2000) and bamecan overexpression is sufficient to cause cell transformation in fibroblasts (Ghiselli and lozzo, 2000). Bamacan's importance in the lens is implied by recent evidence indicating that it is upregulated in human age-related cataracts (Hawse et al., 2003). It will be particularly interesting to determine whether this leads to an increase in the intracellular or extracellular form of the protein.

\section{Expression of integrins}

Attachment to the extracellular matrix depends on the presence of membrane-spanning integrins which bind extracellularly to ECM components and intracellularly to cytoskeletal components and signal transduction proteins. Integrin-mediated signals transmit information from the ECM which can affect survival, proliferation, and differentiation of the cell (outside-in signaling). Conversely, signals originating inside the cell may be transmitted via integrins to alter adhesion to the extracellular matrix (inside-out signaling), thus affecting cell migration. In the embryonic chicken lens, the primary integrins are $\alpha 3 \beta 1$, a fibronectin receptor, and $\alpha 6 \beta 1$, a laminin receptor (Menko etal., 1998). Integrin $\beta 3$ is also expressed in the embryonic chicken lens (Walker et al., 2002b), along with its obligate partner, $\alpha v$ (Menko and Walker, 2004). It is not yet clear whether the integrins found in the chicken lens are also the major integrins in mammalian lenses. At present, several investigators have found $\beta 1$ integrin in human lenses (NEIBank; http://neibank.nei.nih.gov/) ( Duncan et al., 2000; Chauhan et al., 2002; Mathew et al., 2003). In addition, integrins $\alpha 2,3$, and 5 have been found in human lens material (Duncan et al., 2000;Mathew et al., 2003) and $\alpha 6 \mathrm{~A}$ integrin has been reported in the mouse lens (Yoshino et al., 2001).

An interesting switch in $\alpha 6$ isoform expression is associated with fiber cell differentiation in the embryonic chick lens, with $\alpha 6 \mathrm{~B}$ being the predominant form in the epithelial cells and $\alpha 6 \mathrm{~A}$ the major form in the fiber cells (Walker and Menko, 1999). The two $\alpha 6$ subunits differ by 18 amino acids in the cytoplasmic domain, suggesting that they may be regulated differently or participate in different signaling pathways (Hogervorst et al., 1991). In addition, an uncleaved form of $\alpha 6$ integrin becomes progressively more
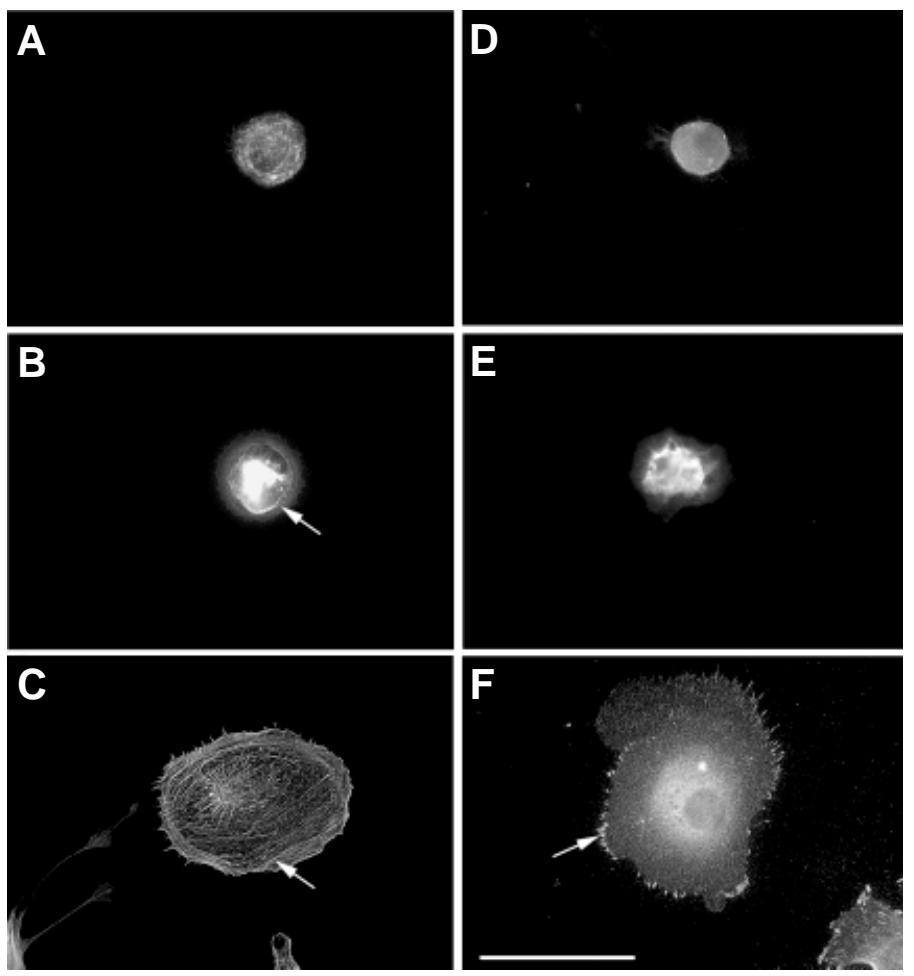

Fig. 2. Attachment of lens epithelial cells to fibronectin. Rabbit lens epithelial cells (N/N1003) were centrifuged onto fibronectin-coated slides $(35 \times \mathrm{g})$, incubated as indicated, and stained with phalloidin to detect $F$ actin $(A-C)$ or with anti-vinculin antibody for immunocytochemical localization of vinculin (D-F). (A,D) Incubation for $5 \mathrm{~min}, 4^{\circ} \mathrm{C}$. Cells attach via integrin binding to extracellular matrix components, but attachments are not linked to the cytoskeleton. Cytoskeletal components are indistinct, cells do not spread, and no focal adhesions are formed. (B,E) Incubation for $5 \mathrm{~min}, 37^{\circ} \mathrm{C}$. Adhesion is strengthened by attachment to the cytoskeleton, an enzymatic process requiring incubation at $37^{\circ} \mathrm{C}$. Actin staining shows that actin polymerization has occurred and cortical F-actin has been assembled (arrow in B). Cells begin to spread and vinculin accumulates. (C,F) Incubation for $2 \mathrm{~h}, 37^{\circ} \mathrm{C}$. Cells are tightly attached, highly spread, and actin is organized into stress fibers (arrow in C). Numerous focal adhesion plaques have formed along the cell periphery (arrow in F). Scale bar, $25 \mu \mathrm{m}$. 
abundant as lens epithelial cells differentiate into lens fibers (Walker etal., 2002a). Although this form is not endoproteolytically processed, it is expressed at the cell surface and associates with signaling molecules such as Shc and Grb2 (Walker et al., 2002a).

The localization of integrins in the lens is somewhat unusual, since $\beta 1$ integrin has been detected on the apical membrane surface along the epithelial-fiber interface, as well as on the basolateral membranes (Menko and Philp, 1995). This contrasts with the expression pattern seen in other epithelial tissues, where tight junctions at apical cell-cell boundaries restrict integrin expression to the basolateral membrane (Menko and Philp, 1995). This unusual feature of lens fiber cells may enable the anterior tips of elongating fiber cells to form attachments and migrate along the epithelial cells at the epithelial-fiber interface. The extracellular ligand for integrins at this interface remains a mystery, however, since there are no reports of extracellular matrix expression in this region.

\section{Calcium in lens epithelial cell migration}

Calcium plays a major role in regulating cell migration in many cell types. Growth factors and other signals that induce cell migration often produce regular oscillations in cytoplasmic calcium concentration, which have been shown to modulate the rate of migration (Komuro and Rakic, 1996). Each successive wave of elevated calcium concentration is correlated with the disassembly of focal adhesions, which are then reformed when calcium concentrations decline (Giannone et al., 2002). In the lens, physiological concentrations of EGF, PDGF, and other agents induce calcium oscillations, particularly in the equatorial epithelium, where cells proliferate and migrate prior to differentiation (Churchill and Louis, 1999; Collison and Duncan, 2001). Moreover, the high degree of intracellular coupling in the lens (Kuszak et al., 1985) leads to coupling of these calcium oscillations (Churchill and Louis, 1999; Collison and Duncan, 2001), providing a possible mechanism for coordinating the movement of the epithelial cell sheet as a whole. Calcium stores in the endoplasmic reticulum seem to be sufficient for maintaining calcium oscillations in the lens, since oscillations continue even in the absence of extracellular calcium (Williams et al., 2001). Since this organelle remains intact in the differentiating fiber cells until elongation is complete (Bassnett, 1995), it is potentially able to sustain calcium oscillations throughout the elongation process.

Calcium waves can be initiated by the action of inositol $(1,4,5)$ triphosphate (IP3), the product of phospholipase $C$ dependent degradation of the polyphosphoinositide, PI(4,5)P2 (Taylor, 2002)or by cyclic ADP-ribose(Churchill and Louis, 1998), which is synthesized by the membrane spanning glycoprotein, ADP-ribosyl cyclase (also called CD38). Both phospholipase C (Vivekanandan and Lou, 1989) and ADP-ribosyl cyclase (Khoo and Chang, 1999) are expressed in lens. Moreover, lens phospholipase $\mathrm{C}$ is activated by growth factors that initiate calcium waves, such as EGF and PDGF (Vivekanandan and Lou, 1989). Although the physiological role of ADP-ribosyl cyclase in the lens is not yet clear, a growing body of evidence suggests that cyclic ADP-ribose may be a second messenger downstream of G-protein coupled receptors (Higashida et al., 2001).

Since calcium concentrations above $1 \mu \mathrm{M}$ can uncouple cells by closing gap junctions (Crow et al., 1994) it is important to note that the intracellular calcium oscillations produced by physiological concentrations of growth factors do not elevate intracellular calcium concentrations above about $500 \mathrm{nM}$ (Collison and Duncan, 2001). Consistent with this observation, physiological concentrations of EGF activate PKC $\alpha$ and PKC $\beta$ in lens epithelial cells, but do not activate PKC $\gamma$ (Seth et al., 2001), the isoform that regulates gap junction closure (Lin et al., 2003). Since higher concentrations of calcium may damage lens cells by activating proteases such as the lens-specific calpain, Lp82 (Shearer et al., 1998), closure of gap junctions protects the epithelial cell sheet by isolating damaged cells with excessive calcium concentrations. While it is important to maintain cytoplasmic calcium below $1 \mu \mathrm{M}$, some minimum calcium concentration is necessary for cell-tomatrix adhesion, since chelation of intracellular calcium by BAPTAAM and EGTA has been shown to prevent attachment of integrins to the cytoskeleton in an epithelial cell line (Nebe et al., 1996).

Calcium exerts its effects on cell migration in numerous ways (Fig. 3). Increases in calcium concentration promote the activity of myosin light chain kinase (MLCK), a calcium/calmodulin dependent enzyme that stimulates myosin-dependent contraction of the cytoskeleton by phosphorylating the regulatory myosin light chain (Ikebe et al., 1986)(Fig. 3). Calcium also leads to the activation of PKC $\alpha$, which promotes turnover and recycling of integrins by phosphorylating ezrin ( $\mathrm{Ng}$ et al., 2001), an actin binding ERM protein, which is expressed in the lens (Bagchi etal., 2004). Finally, calcium elevation has been shown to increase autophosphorylation of focal adhesion kinase (FAK) at Y397 (Giannone et al., 2002), which in turn recruits activated Src (Schaller et al., 1994) and leads to focal adhesion disassembly (Frame et al., 2002).

Recent studies suggest that Src activation induces focal adhesion disassembly by promoting formation of a complex containing FAK, Erk1/2 and calpain 2 at the focal adhesion (Carragher et al., 2003). Erk1/2 in turn phosphorylates calpain 2, increasing its proteolytic activity. Once activated, calpain 2 cleaves FAK, leading to disassembly of the focal adhesion (Carragher et al., 2003) (Fig. 3). Interestingly, Erk1/2 (Walker etal., 2002b), FAK (Weber and Menko, 2003), and calpain 2 (Reed et al., 2003) all seem to have a similar localization pattern along the membranes of elongating lens fiber cells, raising the possibility that the migration of elongating lens fiber cells along the capsule and along the epithelial-fiber interface may also proceed by a mechanism involving FAK, Erk, and calpain.

Recruitment of active Src to focal adhesions also affects migration by regulating the activity of the small GTP-ases, Rho and Rac (Frame et al., 2002). These G-proteins are known to regulate cell movements through their effects on the actin cytoskeleton (Etienne-Manneville and Hall, 2002). For example, Rho kinase, a downstream effector of Rho, regulates myosin light chain, leading ultimately to the activation of myosin ATPase activity and the contraction of the actin cytoskeleton (Fukata etal., 2001;Katoh et al., 2001). Src-dependent phosphorylation of the Rho-specific GTPase activating protein, p190 RhoGAP, leads to inactivation of Rho (Arthur and Burridge, 2001;Brouns et al., 2001), downregulating the contraction phase of cell migration (Fig. 3). In addition, Src-dependent phosphorylation of the adaptor protein, p130Cas, couples integrin-dependent adhesion to activation of Rac (Klemke et al., 1998). This, in turn, releases cortactin, an actin-binding protein that mediates the stimulation of actin polymerization by the Arp $2 / 3$ complex, thus initiating 
lamellipodial extension (Vidal et al., 2002). Rac activation also stimulates myosin dependent contraction through activation of the Rac effector, Pak1 (Chew et al., 1998)(Fig. 3).

It is interesting to note that elevated calcium may both stimulate contraction via MLCK and activation of Rac (Chew et al., 1998) and inhibit contraction via Src-dependent downregulation of Rho (Fukata et al., 2001; Katoh et al., 2001) (Fig. 3). This apparent contradiction may be resolved by the observation that cytoskeletal contractions in the lamellipodia and in the trailing edge appear to be independently regulated (Chew et al., 1998). MLCK is specifically targeted to lamellipodial extensions in migrating cells, and does not appear to be involved in retraction of the trailing edge of the cell (Chew et al., 1998). This observation raises the possibility that calcium-dependent contraction and calciumdependent relaxation may occur in different regions of the cell. Thus, periodic alterations in cytoplasmic calcium concentration have the potential to coordinate regional contractions of the cytoskeleton with actin-driven protrusion of lamellipodia, and focal adhesion turnover (see Fig. 3).

In lens epithelial cells, Rho and Rac are activated in response to EGF and bFGF, with a concomitant induction of stress fibers, membrane ruffles, and focal adhesions (Maddala et al., 2003). These effects are blocked by specific inhibitors of Rho-family GTPases, demonstrating the involvement of these GTPases in the signaling pathways leading to cytoskeletal rearrangements in the lens (Maddala et al., 2003). The in vivo importance of Rhofamily small GTPases in the lens has been demonstrated by lensspecific expression of the inhibitor, exoenzymeC3, in transgenic mice (Rao et al., 2002). Transgenic animals show defects in fiber cell organization, elongation, and differentiation, consistent with a role for these G-proteins in multiple cellular functions, including cell migration and cell-matrix adhesion. Moreover, the Rho isoform, RhoB, is localized along membranes of elongating fiber cells of postnatal mouse lenses, with high concentrations in the basal tips adjacent to the capsule (Maddala et al., 2001).

Although the migration of elongating fiber cells along the lens capsule and epithelial-fiber interface differs in some respects from migration of fibroblasts or epithelial cells in culture, the localization of proteins with known functions in cell-matrix adhesion and migration at the tips of elongating fiber cells suggests that the underlying mechanisms may be similar. Several such proteins have been identified in a two-dimensional array at the basal tips of fiber cells, called the basement membrane complex (Bassnett etal., 1999). This complex, which remains attached to the capsule when the capsule and fiber cells are stripped apart, contains actin, myosin, FAK, MLCK, caldesmon, and paxillin. N-cadherin forms a hexagonal pattern on the capsule surrounding the complex, demarcating the lateral fiber cell membranes. Characteristic focal adhesion proteins that have not been detected in the BMC include alpha-actinin, zyxin, vinculin and talin. However, actin staining in the intact lens indicated that the structure of the basement complex was changed by stripping the capsule from the fiber cells, raising the possibility that some proteins might have been lost during the stripping procedure (Bassnett et al., 1999). Basal tips of elongating fibers are also rich in $\beta 1$ and $\alpha 6$ integrins (Menko and Philp, 1995) (Walker and Menko, 1999), providing a means for connecting integrin-binding proteins in the basement membrane complex, such as paxillin and FAK, to the extracellular matrix (Bassnett et al., 1999).
Two important actin-binding proteins, tropomodulin and tropomyosin, are also enriched in the basal and apical tips of the fibers (Lee et al., 2000). Tropomodulin is an actin capping protein that binds the pointed end of growing actin fibers, limiting their length. Binding of tropomodulin is greatly enhanced by tropomyosin, an actin binding protein that binds along the length of actin fibers, stabilizing them. Tropomodulin is not expressed in cells of the central epithelium of the embryonic chick lens, but can be detected in the cytoplasm of the annular pad cells, (Lee et al., 2000; Woo et al., 2000), suggesting that it may have some role in differentiation. In the elongating fiber cells, tropomodulin is localized along the lateral membranes and in discreet foci at the apical and basal tips of the cells, which do not co-localize with F-actin and tropomyosin (Lee et al., 2000). When fiber cells are separated from the capsule, these foci remain with the fiber cell tips, in contrast to actin and other components of the basement membrane

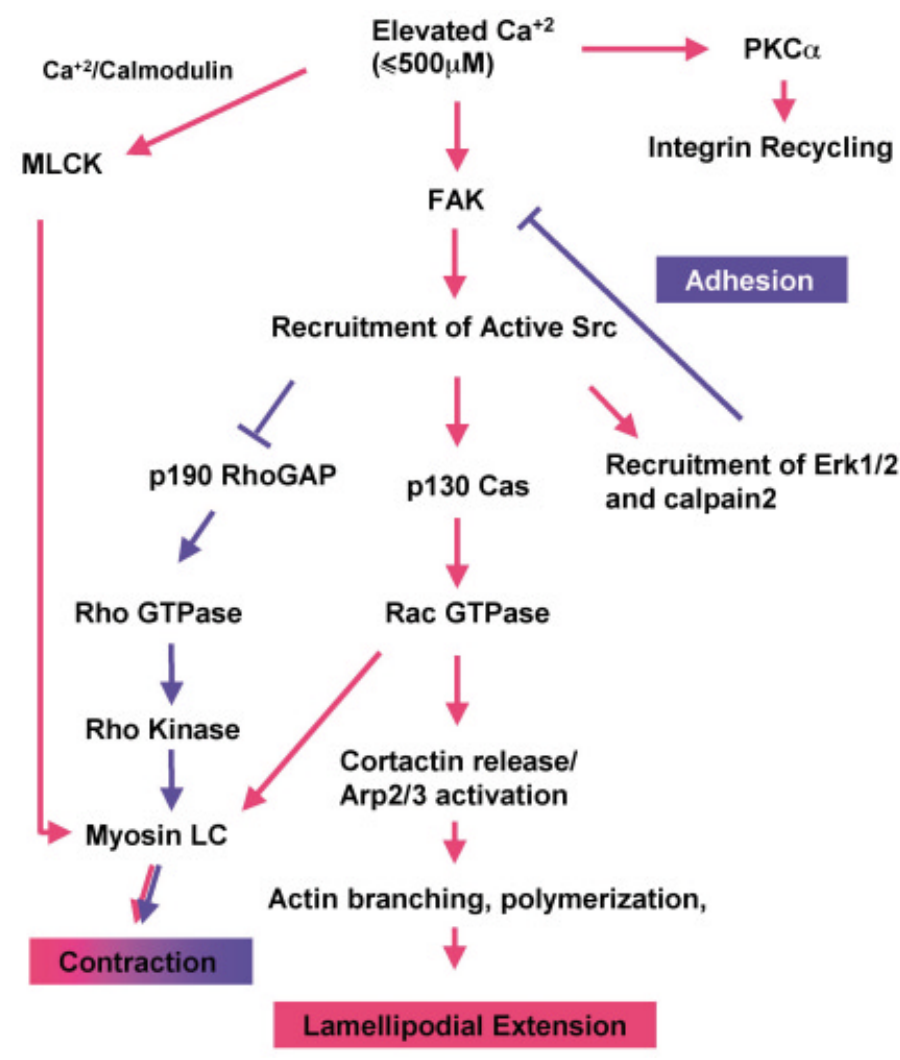

Fig. 3. Calcium dependent regulation of cell migration. Multiple pathways are activated by periodic increases in intracellular calcium. Calcium activates MLCK via a calmodulin dependent pathway, leading to myosin light chain phosphorylation and myosin dependent contraction. It also promotes autophosphorylation of FAK, leading to recruitment of active Src to focal adhesions, which in turn downregulates signaling through Rho and stimulates signaling through Rac. The presence of active Src at the focal adhesion also recruits Erk $1 / 2$ and calpain 2, leading to FAK cleavage and focal adhesion disassembly, thus reducing cell adhesion. Finally, elevated calcium levels activate $P K C \alpha$, which promotes migration by regulating the intracellular trafficking of integrins. Red indicates pathways that are stimulated by elevated calcium; blue indicates those that are downregulated. The opposing signals regulating myosin dependent contraction are likely to be targeted to different regions of the cell. 
complex, which remain attached to the capsule. Tropomodulin foci disappear from the tips of fiber cells after suture formation, although tropomodulin and other membrane skeleton proteins remain associated with the lateral plasma membranes of fiber cells even within the lens nucleus (Lee et al., 2000). Although tropomodulin has not been shown to play a role in cell migration, its ability to regulate actin polymerization and its localization at the tips of differentiating fibers, suggest that it may regulate some aspect of the elongation process.

Another potential regulator of lens cell migration is Cdk5, a proline-directed serine/threonine kinase structurally related to the cyclin-dependent kinases (Meyerson et al., 1992). Like many proteins involved in adhesion and migration, Cdk5 and its activating protein, p35, are present in high concentrations in the tips of elongating lens fiber cells (Gao et al., 1997; Negash et al., 2002). Moreover, a number of proteins with known roles in cell migration are substrates for Cdk5, including c-Src (Kato and Maeda, 1999), some isoforms of myosin heavy chain (Pato etal., 1996), FAK (Xie et al., 2003), and the Rac effector, PAK1 (Nikolic et al., 1998; Banerjee et al., 2002). Furthermore, overexpression of Cdk5 in cultured lens epithelial cells enhances adhesion to extracellular matrix materials such as collagen IV and fibronectin (Negash et al., 2002). Cdk5 exerts its positive effect on adhesion in cells that are actively spreading and forming focal adhesions. Prior to focal adhesion formation, Cdk5 overexpression has a slight negative effect on cell-matrix attachment (Negash et al., 2002). Thus, the ability of Cdk5 to increase adhesion to the extracellular matrix may be due to an increase in the size or stability of focal adhesions. Recent studies with a corneal epithelial cell line demonstrate that Cdk5 limits the recruitment of active Src to the leading edge (Gao et al., 2004), thus suggesting a mechanism by which it might affect focal adhesion stability.

\section{Summary and future directions}

Recent advances in cell biology have led to rapid advances in the understanding of cell migration (Ridley et al., 2003). Examination of the in vivo expression patterns of extracellular matrix components, integrins, and adhesion proteins in the lens (Table 1) suggests that many of the proteins involved in fibroblast migration will have similar roles in the lens. The lens is surrounded by an elaborated basement membrane composed of collagen IV, laminin, fibronectin (Cammarata et al., 1986) and a variety of proteoglycans, which are necessary for proper adhesion and migration. Integrins capable of binding these extracellular matrix proteins are expressed along fiber cell membranes (Menko and Philp, 1995;Menko et al., 1998). Focal adhesion proteins such as FAK, MLCK, caldesmon, and paxillin, are arranged at the basal tips of elongating fiber cells in an unusual, two-dimensional array referred to as the basement membrane complex (Bassnett et al., 1999). In addition, many signaling proteins known to regulate aspects of fibroblast migration are also expressed in the lens. The Rho family of small GTPases, which controls actin polymerization during fibroblast migration, seems to regulate cell movements in lens cells as well (Maddala et al., 2001;Maddala et al., 2003), and agents that block Rho GTPase activity lead to cataract (Rao et al., 2002). Finally, calcium oscillations, which have been shown to coordinate assembly and disassembly of focal adhesions in fibroblasts (Komuro and Rakic, 1996; Giannone et al., 2002), are associated with growth factor stimulation of the lens, especially in the equatorial region, where cell migration is most apparent (Churchill and Louis, 1998;Churchill and Louis, 1999;Collison and Duncan, 2001). Thus, the expected cellular adhesion machinery and the signaling pathways that coordinate and regulate its operation are present in the lens and are concentrated in regions of active cell migration.

In addition, cell migration in the developing lens has some unusual features, which may reflect novel molecular mechanisms. One of these is the movement of the anterior tips of fiber cells along the anterior surface of the overlying epithelial cells. Although $\beta 1$ and $\alpha 6$ integrins are concentrated in the anterior tips of elongating fiber cells (Menko and Philp, 1995;Walker and Menko, 1999), the extracellular matrix ligands of these integrins have not been detected in this region. Thus, it is not clear how lens fiber cells form the attachments necessary to allow them to migrate along the epithelial-fiber interface. Possibly, the anterior tips of lens fibers form attachments through homotypic interactions involving $\mathrm{N}$-cadherin or IgCAM family of cell adhesion molecules, much as growth cones attach to glial cells during neurite extension (Grumet and Edelman, 1988). Alternatively, extracellular matrix components may yet be discovered in this region, which may serve as ligands for integrin-dependent attachment. Another unusual feature of lens fiber cell migration is the detachment of the cells from the capsule when elongation is complete. The mechanism underlying this event and the processes that regulate it are clearly important to lens biology, since detachment is highly correlated with subsequent maturation events such as organelle loss, denucleation, and formation of an intercellular macromolecular diffusion pathway (Bassnett and Beebe, 1992;Bassnett, 1995;Bassnett, 1997;Bassnett, 2002; Shestopalov and Bassnett, 2003). Interestingly, certain general cellular processes, such as mitosis, apoptosis, and transformation, are also associated with detachment from the basement membrane. It is possible that the molecular mechanisms used during these processes have been adapted by differentiating lens fibers to permit the regulated, orderly detachment of cells as they approach the posterior pole. Determining how the general mechanisms of

\section{TABLE 1}

\begin{tabular}{|c|c|c|c|}
\hline Class & Functions & $\begin{array}{l}\text { Proteins Expressed } \\
\text { In Lens }\end{array}$ & References \\
\hline $\begin{array}{l}\text { Extracellular } \\
\text { Matrix } \\
\text { Components }\end{array}$ & $\begin{array}{l}\text { Provide attachment sites } \\
\text { for cells; Bind glycosamino- } \\
\text { glycans, water, nutrients } \\
\text { and growth factors. }\end{array}$ & $\begin{array}{l}\text { Collagen IV, Laminin } \\
\text { Fibronectin } \\
\text { SPARC } \\
\text { Tenascin } \\
\text { Entactin (nidogen) } \\
\text { Perlecan } \\
\text { Bamacan } \\
\text { Thrombospondin-1 }\end{array}$ & $\begin{array}{l}\text { (Timpl and Dziadek, 1986); } \\
\text { (Cammarata et al., 1986) } \\
\text { (Yan et al., 2000) } \\
\text { (Menko et al., 1998) } \\
\text { (Cammarata et al., 1986) } \\
\text { (Dong et al., 2002b); } \\
\text { (Hawse et al., 2003) } \\
\text { (Hiscott et al., 1996); } \\
\text { (Tucker et al., 1997) }\end{array}$ \\
\hline Integrins & $\begin{array}{l}\text { Link extracellular matrix } \\
\text { to intracellular proteins and } \\
\text { signaling pathways }\end{array}$ & $\begin{array}{l}\alpha 2, \alpha 3, \alpha 5, \alpha 6 \mathrm{~A}, \alpha 6 \mathrm{~B} \\
\beta 1, \beta 3\end{array}$ & $\begin{array}{l}\text { (Menko and Philp, 1995); } \\
\text { (Menko et al., 1998); } \\
\text { (Walker and Menko, 1999); } \\
\text { (Duncan et al., 2000); } \\
\text { (Mathew et al., 2003); } \\
\text { (Chauhan et al., 2002); } \\
\text { (Yoshino et al., 2001) }\end{array}$ \\
\hline $\begin{array}{l}\text { Focal } \\
\text { Adhesion } \\
\text { Components }\end{array}$ & $\begin{array}{l}\text { Link cytoplasmic domain } \\
\text { of integrins to cytoskeleton } \\
\text { and signaling proteins }\end{array}$ & $\begin{array}{l}\text { FAK } \\
\text { Paxillin } \\
\text { Vinculin } \\
\text { Caldesmon } \\
\text { Talin }\end{array}$ & $\begin{array}{l}\text { (Bassnett et al., 1999); } \\
\text { (Weber and Menko, 2003) } \\
\text { (Bassnett et al., 1999); } \\
\text { (Beebe, 2001 \#1339) } \\
\text { (Beebe et al., 2001) } \\
\text { (Bassnett } \text { et al., 1999) } \\
\text { (Walker and Menko, 1999) }\end{array}$ \\
\hline
\end{tabular}


cell attachment and migration function in the lens and what specific adaptations have been made to produce the pattern of coordinated cell movements that occur during lens development will be a challenging and exciting area for future research.

\section{References}

ALLEN, P. G. 2003. Actin filament uncapping localizes to ruffling lamellae and rocketing vesicles. Nat. Cell Biol. 5: 972-979.

ARTHUR, W. T., and BURRIDGE, K. 2001. RhoA inactivation by p190RhoGAP regulates cell spreading and migration by promoting membrane protrusion and polarity. Mol. Biol. Cel/12: 2711-2720.

BAGCHI, M., KATAR, M., LO, W., YOST, R., HILL, C., and MAISEL, H. 2004. ERM proteins of the lens. J. Cell. Biochem. 92: 626-630.

BANERJEE, M., WORTH, D., PROWSE, D., and NIKOLIC, M. 2002. Pak1 phosphorylation on $\mathrm{t} 212$ affects microtubules in cells undergoing mitosis. Curr. Biol. 12: 1233-1239.

BASSNETT, S. 1995. The fate of the Golgi apparatus and the endoplasmic reticulum during lens fiber cell differentiation. Invest. Ophthalmol. Vis. Sci.36: 1793-803.

BASSNETT, S. 1997. Fiber cell denucleation in the primate lens. Invest. Ophthalmol. Vis. Sci. 38: 1678-87.

BASSNETT, S. 2002. Lens organelle degradation. Exp. Eye Res. 74: 1-6.

BASSNETT, S., and BEEBE, D. C. 1992. Coincident loss of mitochondria and nuclei during lens fiber cell differentiation. Dev. Dyn. 194: 85-93.

BASSNETT, S., MISSEY, H., and VUCEMILO, I. 1999. Molecular architecture of the lens fiber cell basal membrane complex. J. Cell Sci.112: 2155-2165.

BASSUK, J. A., BIRKEBAK, T., ROTHMIER, J. D., CLARK, J. M., BRADSHAW, A., MUCHOWSKI, P. J., HOWE, C. C., CLARK, J. I., and SAGE, E. H. 1999 Disruption of the Sparc locus in mice alters the differentiation of lenticular epithelial cells and leads to cataract formation. Exp. Eye Res. 68: 321-331.

BEEBE, D. C., VASILIEV, O., GUO, J., SHUI, Y. B., and BASSNETT, S. 2001. Changes in adhesion complexes define stages in the differentiation of lens fiber cells. Invest. Ophthalmol. Vis. Sci. 42: 727-734.

BROUNS, M. R., MATHESON, S. F., and SETTLEMAN, J. 2001. p190 RhoGAP is the principal Src substrate in brain and regulates axon outgrowth, guidance and fasciculation. Nat. Cell Biol. 3: 361-367.

CAMMARATA, P. R., CANTU-CROUCH, D., OAKFORD, L., and MORRILL, A 1986. Macromolecular organization of bovine lens capsule. Tissue Cel/18: 83 $-97$

CARRAGHER, N. O., WESTHOFF, M. A., FINCHAM, V. J., SCHALLER, M. D., and FRAME, M. C. 2003. A novel role for FAK as a protease-targeting adaptor protein: regulation by p42 ERK and Src. Curr. Biol. 13: 1442-50.

CHAUHAN, B. K., REED, N. A., YANG, Y., CERMAK, L., RENEKER, L., DUNCAN, M. K., and CVEKL, A. 2002. A comparative cDNA microarray analysis reveals a spectrum of genes regulated by Pax6 in mouse lens. Genes Cel/s 7: 1267-83.

CHEW, T. L., MASARACCHIA, R. A., GOECKELER, Z. M., and WYSOLMERSKI, R. B. 1998. Phosphorylation of non-muscle myosin II regulatory light chain by p21-activated kinase (gamma-PAK). J. Muscle Res. Cell Motil 19: 839-854.

CHURCHILL, G. C., and LOUIS, C. F. 1998. Roles of Ca2+, inositol trisphosphate and cyclic ADP-ribose in mediating intercellular $\mathrm{Ca} 2+$ signaling in sheep lens cells. J. Cel/ Sci. 111 ( Pt 9): 1217-25.

CHURCHILL, G. C., and LOUIS, C. F. 1999. Imaging of intracellular calcium stores in single permeabilized lens cells. Am. J. Physiol. 276: C426-34.

COLLISON, D. J., and DUNCAN, G. 2001. Regional differences in functional receptor distribution and calcium mobilization in the intact human lens. Invest Ophthalmol. Vis. Sci. 42: 2355-2363.

CROW, J. M., ATKINSON, M. M., and JOHNSON, R. G. 1994. Micromolar levels of intracellular calcium reduce gap junctional permeability in lens cultures. Invest. Ophthalmol. Vis. Sci.35: 3332-41.

DONG, L., CHEN, Y., LEWIS, M., HSIEH, J. C., REING, J., CHAILLET, J. R., HOWELL, C. Y., MELHEM, M., INOUE, S., KUSZAK, J. R., DEGEEST, K., and CHUNG, A. E. 2002a. Neurologic defects and selective disruption of basement membranes in mice lacking entactin-1/nidogen-1. Lab. Invest. 82: 1617-30.
DONG, L. J., HSIEH, J. C., and CHUNG, A. E. 1995. Two distinct cell attachment sites in entactin are revealed by amino acid substitutions and deletion of the RGD sequence in the cysteine-rich epidermal growth factor repeat 2. J. Biol. Chem. 270: 15838-43.

DONG, S., LANDFAIR, J., BALASUBRAMANI, M., BIER, M. E., COLE, G., and HALFTER, W. 2002b. Expression of basal lamina protein mRNAs in the early embryonic chick eye. J. Comp. Neurol. 447: 261-273.

DUNCAN, M. K., KOZMIK, Z., CVEKLOVA, K., PIATIGORSKY, J., and CVEKL, A 2000. Overexpression of PAX6(5a) in lens fiber cells results in cataract and upregulation of (alpha)5(beta)1 integrin expression. J. Cell Sci. 113 ( Pt 18): 3173-85

ETIENNE-MANNEVILLE, S., and HALL, A. 2002. Rho GTPases in cell biology. Nature 420: 629-635.

FENTEANY, G., JANMEY, P. A., and STOSSEL, T. P. 2000. Signaling pathways and cell mechanics involved in wound closure by epithelial cell sheets. Curr. Biol. 10: 831-838

FISCHER, R. S., FRITZ-SIX, K. L., and FOWLER, V. M. 2003. Pointed-end capping by tropomodulin3 negatively regulates endothelial cell motility. J. Cel/ Biol. 161: $371-380$

FRAME, M. C., FINCHAM, V. J., CARRAGHER, N. O., and WYKE, J. A. 2002. vSrc's hold over actin and cell adhesions. Nat. Rev. Mol. Cell Biol. 3: 233-245.

FUKATA, Y., AMANO, M., and KAIBUCHI, K. 2001. Rho-Rho-kinase pathway in smooth muscle contraction and cytoskeletal reorganization of non-muscle cells. Trends Pharmacol. Sci. 22: 32-39.

GAO, C. Y., STEPP, M. A., FARISS, R., and ZELENKA, P. S. 2004. Cdk5 regulates activation and localization of Src during corneal epithelial wound closure. J. Cell Sci. 117: 4089-4098.

GAO, C. Y., ZAKERI, Z., ZHU, Y., HE, H. Y., and ZELENKA, P. S. 1997. Expression of Cdk-5, p35, and Cdk5-associated kinase activity in the developing rat lens. Dev. Genet. 20: 267-275.

GHISELLI, G., and IOZZO, R. V. 2000. Overexpression of bamacan/SMC3 causes transformation. J. Biol. Chem. 275: 20235-8.

GIANNONE, G., RONDE, P., GAIRE, M., HAIECH, J., and TAKEDA, K. 2002 Calcium oscillations trigger focal adhesion disassembly in human U87 astrocytoma cells. J. Biol. Chem. 277: 26364-71.

GILMOUR, D. T., LYON, G. J., CARLTON, M. B., SANES, J. R., CUNNINGHAM, M. J., ANDERSON, J. R., HOGAN, B. L., EVANS, M. J., and COLLEDGE, W. H. 1998. Mice deficient for the secreted glycoprotein SPARC/osteonectin/BM40 develop normally but show severe age-onset cataract formation and disruption of the lens. EMBO J. 17: 1860-1870.

GRUMET, M., and EDELMAN, G. M. 1988. Neuron-glia cell adhesion molecule interacts with neurons and astroglia via different binding mechanisms. J. Cell Biol. 106: 487-503.

HAWSE, J. R., HEJTMANCIK, J. F., HUANG, Q., SHEETS, N. L., HOSACK, D. A LEMPICKI, R. A., HORWITZ, J., and KANTOROW, M. 2003. Identification and functional clustering of global gene expression differences between human age-related cataract and clear lenses. Mol. Vis. 9: 515-537.

HIGASHIDA, H., HASHII, M., YOKOYAMA, S., HOSHI, N., CHEN, X. L., EGOROVA, A., NODA, M., and ZHANG, J. S. 2001. Cyclic ADP-ribose as a second messenger revisited from a new aspect of signal transduction from receptors to ADP-ribosyl cyclase. Pharmacol. Ther. 90: 283-96.

HISCOTT, P., SOROKIN, L., SCHLOTZER-SCHREHARDT, U., BLUTHNER, K., ENDRESS, K., and MAYER, U. 1996. Expression of thrombospondin 1 by adult lens epithelium. Exp. Eye Res. 62: 709-712.

HOGERVORST, F., KUIKMAN, I., VAN KESSEL, A. G., and SONNENBERG, A 1991. Molecular cloning of the human alpha 6 integrin subunit. Alternative splicing of alpha 6 mRNA and chromosomal localization of the alpha 6 and beta 4 genes. Eur. J. Biochem. 199: 425-33.

HOLLY, S. P., LARSON, M. K., and PARISE, L. V. 2000. Multiple roles of integrins in cell motility. Exp. Cell Res. 261: 69-74.

HSIEH, J. C., WU, C., and CHUNG, A. E. 1994. The binding of fibronectin to entactin is mediated through the $29 \mathrm{kDa}$ amino terminal fragment of fibronectin and the G2 domain of entactin. Biochem. Biophys. Res. Commun. 199: 1509-17.

IKEBE, M.,HARTSHORNE, D. J., and ELZINGA, M. 1986. Identification, phosphorylation, and dephosphorylation of a second site for myosin light chain kinase on the 20,000dalton light chain of smooth muscle myosin. J. Biol. Chem. 261: 36-39. 
JULIANO, R. L., and HASKILL, S. 1993. Signal transduction from the extracellular matrix. J. Cel/ Biol.120: 577-85.

KATO, G., and MAEDA, S. 1999. Neuron-specific Cdk5 kinase is responsible for mitosis-independent phosphorylation of c-Src at Ser75 in human Y79 retinoblastoma cells. J. Biochem. (Tokyo) 126: 957-961.

KATOH, K., KANO, Y., AMANO, M., ONISHI, H., KAIBUCHI, K., and FUJIWARA, K. 2001. Rho-kinase-mediated contraction of isolated stress fibers. J. Cell Biol.153: 569-584.

KHOO, K. M., and CHANG, C. F. 1999. Characterization and localization of CD38 in the vertebrate eye. Brain Res. 821: 17-25.

KLEMKE, R. L., LENG, J., MOLANDER, R., BROOKS, P. C., VUORI, K., and CHERESH, D. A. 1998. CAS/Crk coupling serves as a «molecular switch» for induction of cell migration. J. Cell Biol. 140: 961-972.

KOMURO, H., and RAKIC, P. 1996. Intracellular Ca2+ fluctuations modulate the rate of neuronal migration. Neuron 17: 275-85.

KUSZAK, J. R., PETERSON, K. L., SIVAK, J. G., and HERBERT, K. L. 1994. The interrelationship of lens anatomy and optical quality. II. Primate lenses. Exp. Eye Res. 59: 521-535.

KUSZAK, J. R., SHEK, Y. H., CARNEY, K. C., and RAE, J. L. 1985. A correlative freeze-etch and electrophysiological study of communicating junctions in crystalline lenses. Curr. Eye Res.4: 1145-53.

KVANSAKUL, M., HOPF, M., RIES, A., TIMPL, R., and HOHENESTER, E. 2001. Structural basis for the high-affinity interaction of nidogen-1 with immunoglobulinlike domain 3 of perlecan. EMBO J. 20: 5342-6.

LANE, T. F., and SAGE, E. H. 1994. The biology of SPARC, a protein that modulates cell-matrix interactions. FASEB J. 8: 163-173.

LEE, A., FISCHER, R. S., and FOWLER, V. M. 2000. Stabilization and remodeling of the membrane skeleton during lens fiber cell differentiation and maturation. Dev. Dyn.217: 257-70.

LIN, D., BOYLE, D. L., and TAKEMOTO, D. J. 2003. IGF-I-induced phosphorylation of connexin 43 by PKCgamma: regulation of gap junctions in rabbit lens epithelial cells. Invest. Ophthalmol. Vis. Sci. 44: 1160-8

MADDALA, R., PENG, Y. W., and RAO, P. V. 2001. Selective expression of the small GTPase RhoB in the early developing mouse lens. Dev. Dyn. 222: 534-7.

MADDALA, R., REDDY, V. N., EPSTEIN, D. L., and RAO, V. 2003. Growth factor induced activation of Rho and Rac GTPases and actin cytoskeletal reorganization in human lens epithelial cells. Mol. Vis. 9: 329-336.

MATHEW, M. R., MCLEAN, S. M., MURRAY, S. B., BENNETT, H. G., WEBB, L. A., and ESAKOWITZ, L. 2003. Expression of CD18, CD49b, CD49c and CD49e on lens anterior capsules in human cataracts. Eye 17: 473-7.

MENKO, A. S., and PHILP, N. J. 1995. Beta 1 integrins in epithelial tissues: a unique distribution in the lens. Exp. Cell Res. 281: 516-521.

MENKO, A. S., and WALKER, J. L. 2004. Role of Matrix and Cell Adhesion Molecules in Lens Differentiation in F. J. Lovicu and M. L. Robinson, eds Development of the Ocular Lens,. Cambridge University Press, Cambridge.

MENKO, S., PHILP, N., VENEZIALE, B., and WALKER, J. 1998. Integrins and development: how might these receptors regulate differentiation of the lens. Ann. NY Acad. Sci. 842: 36-41.

MEYERSON, M., ENDERS, G. H., WU, C. L., SU, L. K., GORKA, C., NELSON, C., HARLOW, E., and TSAI, L. H. 1992. A family of human cdc2-related protein kinases. EMBO J. 11: 2909-2917.

MURPHY-ULLRICH, J. E., LANE, T. F., PALLERO, M. A., and SAGE, E. H. 1995. SPARC mediates focal adhesion disassembly in endothelial cells through a follistatin-like region and the calcium-binding EF-hand. J. Cell Biochem. 57: 341-350.

NEBE, B., BOHN, W., SANFTLEBEN, H., and RYCHLY, J. 1996. Induction of a physical linkage between integrins and the cytoskeleton depends on intracellular calcium in an epithelial cell line. Exp. Cell Res. 229: 100-10.

NEGASH, S., WANG, H. S., GAO, C., LEDEE, D., and ZELENKA, P. 2002. Cdk5 regulates cell-matrix and cell-cell adhesion in lens epithelial cells. J. Cell Sci. 115: $2109-17$.

NG, T., PARSONS, M., HUGHES, W. E., MONYPENNY, J., ZICHA, D., Gautreau, A., ARPIN, M., GSChMEISSNER, S., VERVEER, P. J.,
BASTIAENS, P. I., and PARKER, P. J. 2001. Ezrin is a downstream effector of trafficking PKC-integrin complexes involved in the control of cell motility. EMBO J. 20: 2723-2741

NIKOLIC, M., CHOU, M. M., LU, W., MAYER, B. J., and TSAI, L. H. 1998. The p35/ Cdk5 kinase is a neuron-specific Rac effector that inhibits Pak1 activity. Nature 395: 194-198

OHARAZAWA, H., IBARAKI, N., LIN, L. R., and REDDY, V. N. 1999. The effects of extracellular matrix on cell attachment, proliferation and migration in a human lens epithelial cell line. Exp. Eye Res. 69: 603-610.

PATO, M. D., SELLERS, J. R., PRESTON, Y. A., HARVEY, E. V., and ADELSTEIN R. S. 1996. Baculovirus expression of chicken nonmuscle heavy meromyosin II-B. Characterization of alternatively spliced isoforms. J. Biol. Chem. 271: 2689-95.

PIATIGORSKY, J. 1981. Lens differentiation in vertebrates: A review of cellular and molecular features. Differentiation 19: 134-152.

RAO, V., WAWROUSEK, E., TAMM, E. R., and ZIGLER, S., JR. 2002. Rho GTPase inactivation impairs lens growth and integrity. Lab. Invest. 82: 231-9.

REED, N. A., CASTELLINI, M. A., MA, H., SHEARER, T. R., and DUNCAN, M. K. 2003. Protein expression patterns for ubiquitous and tissue specific calpains in the developing mouse lens. Exp. Eye Res. 76: 433-43.

RIDLEY, A. J., SCHWARTZ, M. A., BURRIDGE, K., FIRTEL, R. A., GINSBERG, M H., BORISY, G., PARSONS, J. T., and HORWITZ, A. R. 2003. Cell migration: integrating signals from front to back. Science 302: 1704-9.

SCHALLER, M. D., HILDEBRAND, J. D., SHANNON, J. D., FOX, J. W., VINES, R R., and PARSONS, J. T. 1994. Autophosphorylation of the focal adhesion kinase, pp125FAK, directs SH2-dependent binding of pp60src. Mol. Cell Biol. 14: $1680-8$.

SETH, R. K., HAQUE, M. S., and ZELENKA, P. S. 2001. Regulation of c-fos induction in lens epithelial cells by 12(S)HETE-dependent activation of PKC. Invest. Ophthalmol. Vis. Sci. 42: 3239-46

SHEARER, T. R., MA, H., SHIH, M., HATA, I., FUKIAGE, C., NAKAMURA, Y., and AZUMA, M. 1998. Lp82 calpain during rat lens maturation and cataract formation Curr. Eye Res. 17: 1037-43

SHESTOPALOV, V. I., and BASSNETT, S. 2003. Development of a macromolecular diffusion pathway in the lens. J. Cell Sci. 116: 4191-9.

TAYLOR, C. W. 2002. Controlling calcium entry. Cel/111: 767-9.

TIMPL, R., and BROWN, J. C. 1996. Supramolecular assembly of basement membranes. BioEssays 18: 123-32.

TIMPL, R., and DZIADEK, M. 1986. Structure, development, and molecular pathology of basement membranes. Int. Rev. Exp. Pathol. 29: 1-112.

TUCKER, R. P., HAGIOS, C., CHIQUET-EHRISMANN, R., and LAWLER, J. 1997. In situ localization of thrombospondin-1 and thrombospondin-3 transcripts in the avian embryo. Dev. Dyn.208: 326-337.

VIDAL, C., GENY, B., MELLE, J., JANDROT-PERRUS, M., and FONTENAYROUPIE, M. 2002. Cdc42/Rac1-dependent activation of the p21-activated kinase (PAK) regulates human platelet lamellipodia spreading: implication of the cortical-actin binding protein cortactin. Blood100: 4462-4469.

VIVEKANANDAN, S., and LOU, M. F. 1989. Evidence for the presence of phosphoinositide cycle and its involvement in cellular signal transduction in the rabbit lens. Curr. Eye Res. 8: 101-111.

WALKER, J. L., and MENKO, A. S. 1999. alpha6 Integrin is regulated with lens cell differentiation by linkage to the cytoskeleton and isoform switching. Dev. Biol. 210: 497-511.

WALKER, J. L., ZHANG, L., and MENKO, A. S. 2002a. A signaling role for the uncleaved form of alpha 6 integrin in differentiating lens fiber cells. Dev. Biol 251: 195-205

WALKER, J. L., ZHANG, L., ZHOU, J., WOOLKALIS, M. J., and MENKO, A. S 2002b. Role for alpha 6 integrin during lens development: Evidence for signaling through IGF-1R and ERK. Dev. Dyn. 223: 273-84

WEBER, G., and MENKO, S. 2003. JNK regulation of Bcl-2 association with FAK and paxillin in differentiating lens fiber cells. Invest. Ophthalmol. Vis. Sci. 44: 952 Suppl.

WILLIAMS, M. R., RIACH, R. A., COLLISON, D. J., and DUNCAN, G. 2001. Role of the endoplasmic reticulum in shaping calcium dynamics in human lens cells. Invest. Ophthalmol. Vis. Sci. 42: 1009-17. 
WOO, M. K., LEE, A., FISCHER, R. S., MOYER, J., and FOWLER, V. M. 2000. The lens membrane skeleton contains structures preferentially enriched in spectrinactin or tropomodulin-actin complexes. Cell Motil. Cytoskeleton 46: 257-68.

XIE, Z., SANADA, K., SAMUELS, B. A., SHIH, H., and TSAI, L. H. 2003. Serine 732 phosphorylation of FAK by Cdk5 is important for microtubule organization, nuclear movement, and neuronal migration. Cel/114: 496-482.

YAN, Q., CLARK, J. I., and SAGE, E. H. 2000. Expression and characterization of
SPARC in human lens and in the aqueous and vitreous humors. Exp. Eye Res. 71: 81-90.

YOSHINO, M., KUROSAKA, D., OBAZAWA, M., TAKAYAMA, F., THORSTEINSDOTTIR, S., ROELEN, B. A., FREUND, E., GASPAR, A. C., SONNENBERG, A., and MUMMERY, C. L. 2001. [Presence of alpha 5 beta 1 integrin and fibronectin in the anterior subcapsular cataract]. Nippon Ganka Gakkai Zasshi105: 83-7. 